\title{
Effect of Sulphur and Iron Fertilization on Growth and Yield of Greengram [Vigna radiata L.]
}

\author{
Atul Kumar Saini and Rajesh Singh* \\ Department of Agronomy, Sam Higginbottom University of Agriculture, Technology and \\ Sciences, Allahabad - 211007, U.P, India \\ *Corresponding author:
}

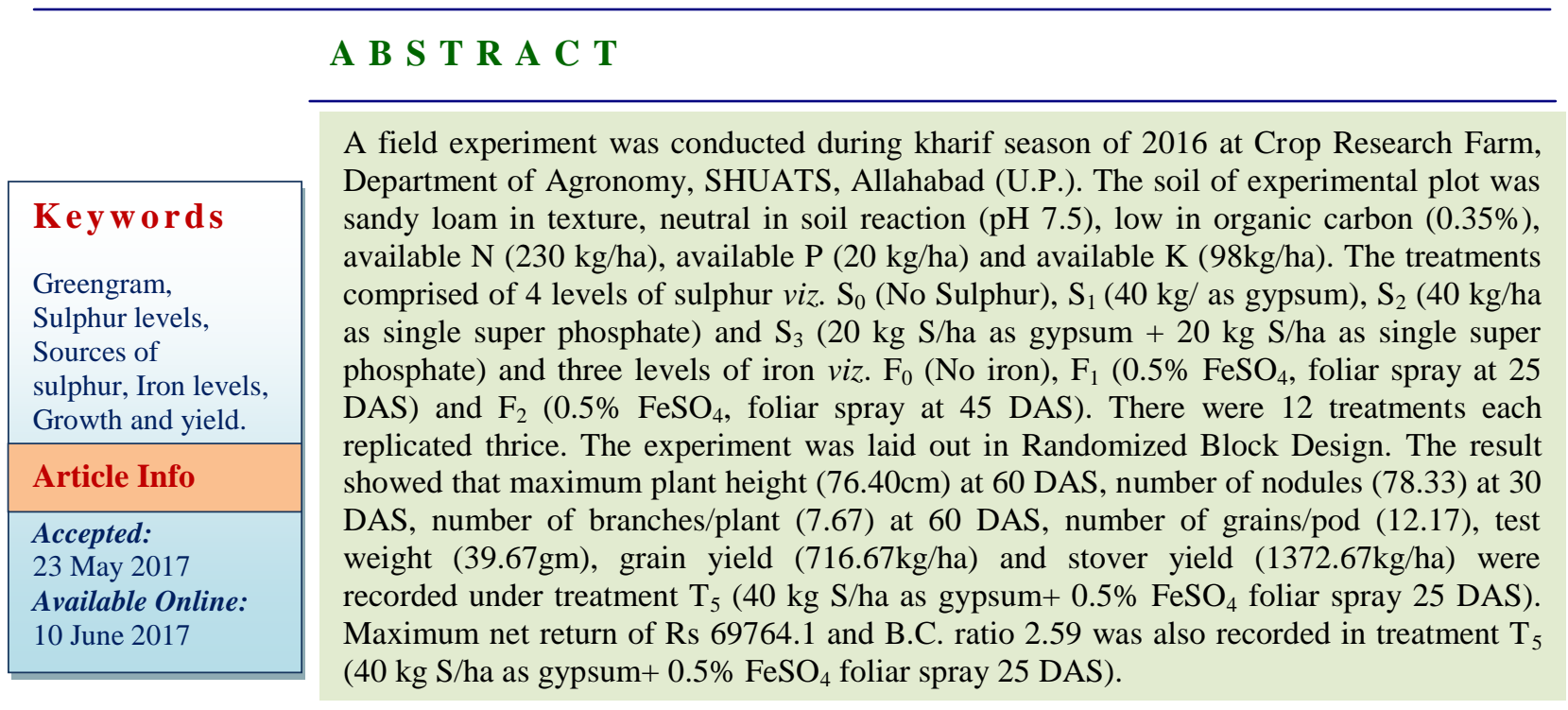

\section{Introduction}

Greengram (Vigna radiata $\mathrm{L}$.) is an important legume crop of Asian origin, and is widely cultivated in the countries of Asia, Australia and Africa continents (Yang et al., 2008). Like other pulses it offers a cheap source of protien. It is an important pulse crop ranked as the second most drought resistant crop after soybean. Mung bean has more protein contents and better digestibility than any other pulse crop (Tabassum et al., 2010). Mung bean grains contain $51 \%$ carbohydrates, $26 \%$ protein, $10 \%$ moisture and $3 \%$ vitamins. The residue of green gram is also used as feed for animals and enhances the soil fertility (Asaduzzaman, 2008). A balanced fertilization of macro and micro nutrients is very important for high yield and high quality products (Sawan et al., 2001). Mung bean is considered as poor man's meat as it contains approximately triple amount of protein as compared to rice. It synthesizes nitrogen in symbiosis with rhizobia and increases soil fertility and biomass of soil. Iron (Fe) is an essential nutrient for plant growth and development and it is involved in chlorophyll and thylakoid synthesis and chloroplast development. Although, total iron content of soils is much higher than requirement of plant but its bioavailability is limited (Guerinot and Yi, 1994). Foliar feeding is a new and 
controversal technique of feeding plants by applying liquid fertilizer directly to their leaves (Bernal et al., 2007 and Baloch et al., 2008). Sulphur has been recognised as an essential major nutrient for plant and it ranks $4^{\text {th }}$ macronutrient after $\mathrm{N}, \mathrm{P}$ and $\mathrm{K}$ because of its role is synthesis of proteins, vitamins, enzyme and flavoured compounds in plant. About $90 \%$ of plant sulphur is present in amino acid viz. Methionine, cystine and Cysteine (Tandon and Messiet, 2002). These amino acids are the building blocks of protein. It is also involved in the formation of chlorophyll and activation of enzymes (Mengel and Krikby, 1987) and due to this sulphur is crucial for pulse crops. Sulphur is also a constituent of vitamin biotine and thiamine and also of iron-sulphur protein ferrodoxin. Sulphur also enhances quality of grains by increasing its nutritional values. Thus, an experiment was conducted to study the effect of sulphur and iron fertilization on growth and yield of green gram.

\section{Materials and Methods}

A field experiment was conducted during kharif season of 2016 at Crop Research Farm, Department of Agronomy, SUATS, Allahabad (U.P.) which lies between $25^{\circ} 24$ ' 42 " $\mathrm{N}$ latitude and $81^{\circ} 50$ ' 56 " E latitude and at an altitude of $98 \mathrm{~m}$ above mean sea level. The soil of experimental plot was sandy loam in texture, neutral in soil reaction $(\mathrm{pH} 7.5)$, low in organic carbon $(0.35 \%)$, available $\mathrm{N}$ (230 kg/ha), available $\mathrm{P}(20 \mathrm{~kg} / \mathrm{ha})$ and available K (98 kg/ha). The treatments comprised of 4 levels of sulphur viz. $\mathrm{S}_{0}$ (No Sulphur), $S_{1}\left(40 \mathrm{~kg} /\right.$ as gypsum), $S_{2}(40 \mathrm{~kg} / \mathrm{ha}$ as single super phosphate) and $S_{3}(20 \mathrm{~kg} \mathrm{~S} / \mathrm{ha}$ as gypsum $+20 \mathrm{~kg} \mathrm{~S} / \mathrm{ha}$ as single super phosphate) and three levels of iron viz. $\mathrm{F}_{0}$ (No iron), $\mathrm{F}_{1}\left(0.5 \% \mathrm{FeSO}_{4}\right.$, foliar spray at 25 DAS $)$ and $\mathrm{F}_{2}\left(0.5 \% \mathrm{FeSO}_{4}\right.$, foliar spray at 45 DAS). There were 12 treatments and each replicated thrice. The experiment was laid out in Randomized Block Design. Pre-harvest observation viz. Plant height, number of nodules/plant, CGR, number of branch/plant and dry weight/plant were recorded. Post harvest observation viz. Number of pods/plant, no. of grains/pod, test weight, harvest index, grain and stover yield were also recorded. In addition to pre and post harvest observation, economics of treatments was also studied to find out the best treatment combination for higher yield, maximum net return and highest $\mathrm{B}: \mathrm{C}$ ratio of mungbean.

\section{Results and Discussion}

\section{Effect of sulphur}

Growth and yield attributes viz. Plant height, number of branches/plant, number of nodules/plant, number of grains/pod, test weight and grain yield increased significantly in treatment $\mathrm{T}_{5}$ (40 kg S/ha as gypsum+ $0.5 \%$ $\mathrm{FeSO}_{4}$ foliar spray 25 DAS). However, Dry Weight, Crop Growth Rate, Number of pods per plant and Harvest Index were found to be non-significant with application of sulphur and $0.5 \% \quad \mathrm{FeSO}_{4}$ spray (Table 1). The maximum plant height $(76.40 \mathrm{~cm})$ at $60 \mathrm{DAS}$, maximum number of nodules (78.33) at 30 DAS, maximum number of branches/plant (7.67) at 60 DAS, number of grains/pod (12.17), test weight $(39.67 \mathrm{~g})$, grain yield $(716.67 \mathrm{~kg} / \mathrm{ha})$ were recorded in treatment $\mathrm{T}_{5}$ followedby treatment $\mathrm{T}_{8}(40 \mathrm{~kg} \mathrm{~S} / \mathrm{ha}$ as single super phosphate $+0.5 \% \mathrm{FeSO}_{4}$ foliar spray 25 DAS) and it was found to be at par to treatment $\mathrm{T}_{5}$ (Table 2). These results obtained might be ascribed to process of tissue differentiation from somatic to reproductive meristematic activity and development of floral primordial might have increased with increasing sulphur levels, resulting in more number of flowers and longer pods and higher grains yield. 
Table.1 Effect of sulphur and iron fertilization on dry weight (g), CGR, number of pods/plant and harvest index of greengram

\begin{tabular}{|c|c|c|c|c|c|}
\hline \multicolumn{2}{|r|}{ Treatments } & \multirow{2}{*}{$\begin{array}{c}\text { Dry } \\
\text { Weight (g) at } 60 \\
\text { DAS } \\
15.99\end{array}$} & \multirow{2}{*}{$\begin{array}{l}\text { CGR } \\
\text { at } 60 \\
\text { DAS } \\
0.35\end{array}$} & \multirow{2}{*}{$\begin{array}{c}\text { No. of pods/plant } \\
15.75\end{array}$} & \multirow{2}{*}{$\begin{array}{c}\text { Harvest index } \\
(\%)\end{array}$} \\
\hline $\mathrm{T}_{1}$ & Control & & & & \\
\hline $\mathrm{T}_{2}$ & $\mathrm{~S}_{0}+0.5 \% \mathrm{FeSO}_{4}$ foliar spray (25 DAS) & 16.44 & 0.37 & 15.75 & 15.75 \\
\hline $\mathrm{T}_{3}$ & $\mathrm{~S}_{0}+0.5 \% \mathrm{FeSO}_{4}$ foliar spray (45 DAS) & 17.11 & 0.40 & 16.25 & 16.25 \\
\hline $\mathrm{T}_{4}$ & $40 \mathrm{~kg} \mathrm{~S} / \mathrm{ha}$ as gypsum $+\mathrm{F}_{0}$ & 19.89 & 0.52 & 16.58 & 16.58 \\
\hline $\mathrm{T}_{5}$ & $\begin{array}{l}40 \mathrm{~kg} \mathrm{~S} / \mathrm{ha} \text { as gypsum+ } 0.5 \% \mathrm{FeSO}_{4} \text { foliar spray } \\
(25 \mathrm{DAS})\end{array}$ & 24.75 & 1.00 & 18.42 & 18.42 \\
\hline $\mathrm{T}_{6}$ & $\begin{array}{l}40 \mathrm{~kg} \mathrm{~S} / \mathrm{ha} \text { as gypsum+0.5\% } \mathrm{FeSO}_{4} \text { foliar spray } \\
(45 \mathrm{DAS} \text { ) }\end{array}$ & 17.55 & 0.47 & 17.25 & 17.25 \\
\hline $\mathrm{T}_{7}$ & $40 \mathrm{~kg} \mathrm{~S} / \mathrm{ha}$ as single super phosphate $+\mathrm{F}_{0}$ & 19.00 & 0.43 & 17.17 & 17.17 \\
\hline $\mathrm{T}_{8}$ & $\begin{array}{l}40 \mathrm{~kg} \mathrm{~S} / \text { ha as single super phosphate }+0.5 \% \\
\left.\mathrm{FeSO}_{4} \text { foliar spray ( } 25 \mathrm{DAS}\right)\end{array}$ & 20.66 & 0.64 & 17.33 & 17.33 \\
\hline $\mathrm{T}_{9}$ & $\begin{array}{l}40 \mathrm{~kg} \mathrm{~S} / \text { ha as single super phosphate }+0.5 \% \\
\mathrm{FeSO}_{4} \text { foliar spray (45 DAS) }\end{array}$ & 18.00 & 0.49 & 17.25 & 17.25 \\
\hline $\mathrm{T}_{10}$ & $\begin{array}{l}20 \mathrm{~kg} \mathrm{~S} / \mathrm{ha} \text { as gypsum }+20 \mathrm{~kg} \mathrm{~S} / \mathrm{ha} \text { as single } \\
\text { super phosphate }(1: 1)+\mathrm{F}_{0} \\
20 \mathrm{~kg} \mathrm{~S} / \mathrm{ha} \text { as gypsum }+20 \mathrm{~kg} \mathrm{~S} / \mathrm{ha} \text { as single }\end{array}$ & 18.44 & 0.43 & 16.58 & 16.58 \\
\hline $\mathrm{T}_{11}$ & $\begin{array}{l}\text { super phosphate }(1: 1)+0.5 \% \mathrm{FeSO}_{4} \text { foliar spray } \\
(25 \text { DAS) }\end{array}$ & 19.75 & 0.47 & 16.75 & 16.75 \\
\hline $\mathrm{T}_{12}$ & $\begin{array}{l}20 \mathrm{~kg} \mathrm{~S} / \mathrm{ha} \text { as gypsum }+20 \mathrm{~kg} \mathrm{~S} / \mathrm{ha} \text { as single } \\
\text { super phosphate }(1: 1)+0.5 \% \mathrm{FeSO}_{4} \text { foliar spray } \\
(45 \mathrm{DAS})\end{array}$ & 18.55 & 0.45 & 16.75 & 16.75 \\
\hline & F- test & NS & NS & NS & NS \\
\hline & S. Ed. $( \pm)$ & 2.90 & 0.214 & 0.83 & 0.83 \\
\hline & C. D. $(P=0.05)$ & - & - & - & _ \\
\hline
\end{tabular}


Table.2 Effect of sulphur and iron fertilization on plant height, number of nodules, number of branches/plant and number of grains/pod of greengram

\begin{tabular}{|c|c|c|c|c|c|}
\hline & Treatments & $\begin{array}{l}\text { Plant height at60 } \\
\text { DAS }\end{array}$ & $\begin{array}{c}\text { No. of nodules } \\
\text { at } 30 \\
\text { DAS } \\
\end{array}$ & $\begin{array}{c}\text { No. of } \\
\text { branch/plant } \\
\text { at } 60 \mathrm{DAS} \\
\end{array}$ & $\begin{array}{l}\text { No. of } \\
\text { grains/pod }\end{array}$ \\
\hline $\mathrm{T}_{1}$ & Control & 71.73 & 56.25 & 6.93 & 10.33 \\
\hline $\mathrm{T}_{2}$ & $\mathrm{~S}_{0}+0.5 \% \mathrm{FeSO}_{4}$ foliar spray (25 DAS) & 72.20 & 58.92 & 7.13 & 10.42 \\
\hline $\mathrm{T}_{3}$ & $\mathrm{~S}_{0}+0.5 \% \mathrm{FeSO}_{4}$ foliar spray (45 DAS) & 73.27 & 59.82 & 7.13 & 10.83 \\
\hline $\mathrm{T}_{4}$ & $40 \mathrm{~kg} \mathrm{~S} / \mathrm{ha}$ as gypsum $+\mathrm{F}_{0}$ & 73.73 & 61.08 & 7.20 & 11.17 \\
\hline $\mathrm{T}_{5}$ & $40 \mathrm{~kg} \mathrm{~S} / \mathrm{ha}$ as gypsum $+0.5 \% \mathrm{FeSO}_{4}$ foliar spray (25 DAS) & 76.40 & 78.33 & 7.67 & 12.17 \\
\hline $\mathrm{T}_{6}$ & $40 \mathrm{~kg} \mathrm{~S} / \mathrm{ha}$ as gypsum $+0.5 \% \mathrm{FeSO}_{4}$ foliar spray (45 DAS) & 75.40 & 72.50 & 7.60 & 11.50 \\
\hline $\mathrm{T}_{7}$ & $40 \mathrm{~kg} \mathrm{~S} / \mathrm{ha}$ as single super phosphate $+\mathrm{F}_{0}$ & 73.27 & 61.92 & 7.60 & 11.00 \\
\hline $\mathrm{T}_{8}$ & $\begin{array}{l}40 \mathrm{~kg} \mathrm{~S} / \mathrm{ha} \text { as single super phosphate }+0.5 \% \mathrm{FeSO}_{4} \text { foliar } \\
\text { spray ( } 25 \mathrm{DAS})\end{array}$ & 75.47 & 77.42 & 7.66 & 12.00 \\
\hline $\mathrm{T}_{9}$ & $\begin{array}{l}40 \mathrm{~kg} \mathrm{~S} / \mathrm{ha} \text { as single super phosphate }+0.5 \% \mathrm{FeSO}_{4} \text { foliar } \\
\text { spray (45 DAS) }\end{array}$ & 75.27 & 63.67 & 7.40 & 11.75 \\
\hline $\mathrm{T}_{10}$ & $\begin{array}{l}20 \mathrm{~kg} \mathrm{~S} / \mathrm{ha} \text { as gypsum }+20 \mathrm{~kg} \mathrm{~S} / \mathrm{ha} \text { as single super phosphate } \\
(1: 1)+\mathrm{F}_{0}\end{array}$ & 73.47 & 62.50 & 7.27 & 11.17 \\
\hline $\mathrm{T}_{11}$ & $\begin{array}{l}20 \mathrm{~kg} \mathrm{~S} / \mathrm{ha} \text { as gypsum }+20 \mathrm{~kg} \mathrm{~S} / \mathrm{ha} \text { as single super phosphate } \\
(1: 1)+0.5 \% \mathrm{FeSO}_{4} \text { foliar spray }(25 \mathrm{DAS})\end{array}$ & 75.13 & 65.83 & 7.60 & 11.42 \\
\hline $\mathrm{T}_{12}$ & $\begin{array}{l}20 \mathrm{~kg} \mathrm{~S} / \mathrm{ha} \text { as gypsum }+20 \mathrm{~kg} \mathrm{~S} / \mathrm{ha} \text { as single super phosphate } \\
(1: 1)+0.5 \% \mathrm{FeSO}_{4} \text { foliar spray }(45 \mathrm{DAS})\end{array}$ & 74.40 & 65.75 & 7.60 & 11.25 \\
\hline & F- test & $\mathrm{S}$ & $\mathrm{S}$ & $\mathrm{S}$ & $\mathrm{S}$ \\
\hline & S. Ed. $( \pm)$ & 1.27 & 6.57 & 0.15 & 0.52 \\
\hline & C. D. $(P=0.05)$ & 2.63 & 13.56 & 0.31 & 1.08 \\
\hline
\end{tabular}


Table.3 Effect of sulphur and iron fertilization on test weight (gm), grain yield (kg/ha) and stover yield (kg/ha) of greengram

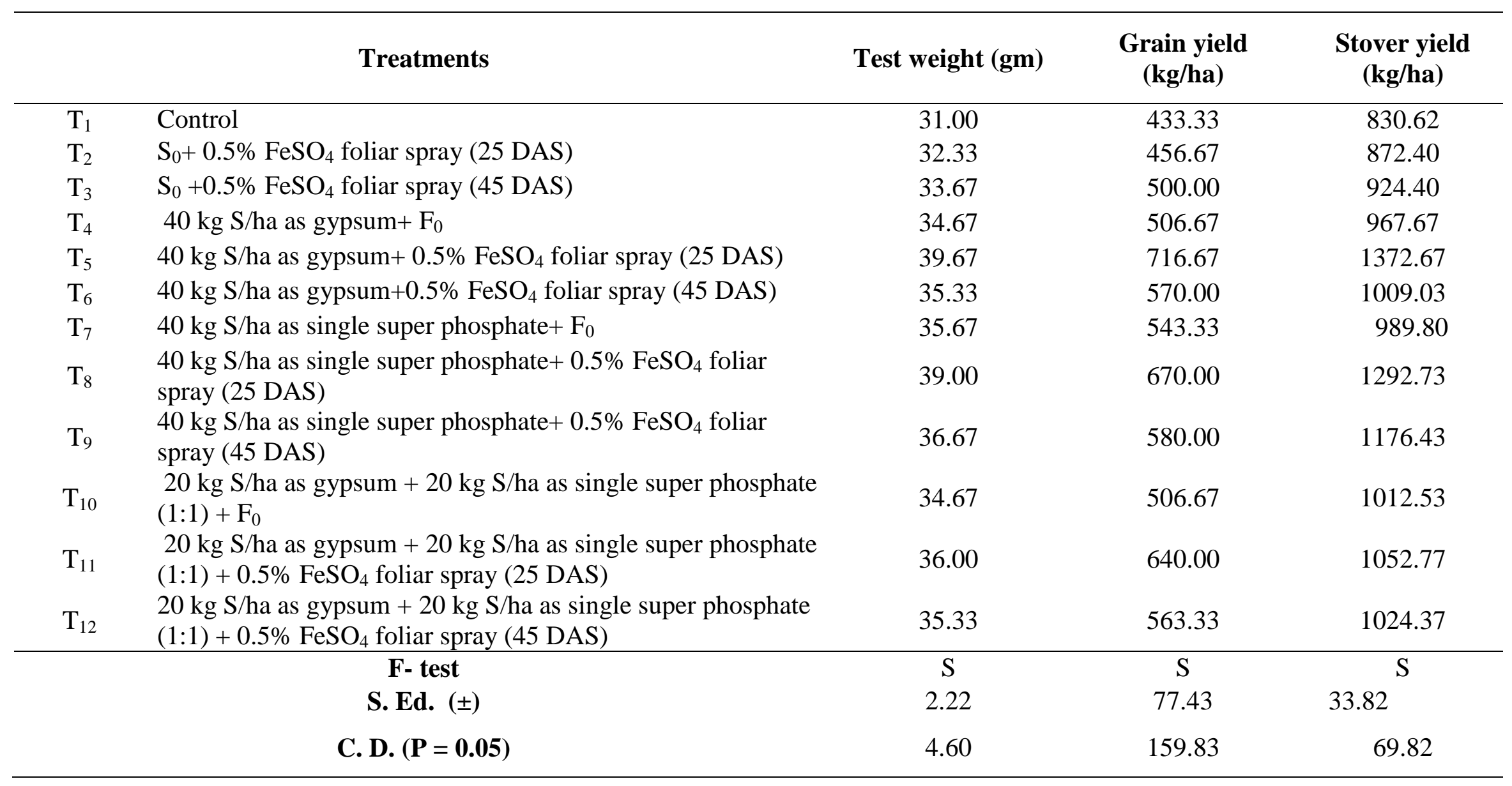


Table.4 Effect of different benefit cost ratio (B:C) of different treatment combination with greengram crop

\begin{tabular}{|c|c|c|c|c|c|c|c|c|}
\hline \multirow{2}{*}{ Treatment } & \multirow{2}{*}{ Cost of Cultivation } & \multicolumn{2}{|c|}{ Yield } & \multicolumn{2}{|c|}{ Sale (₹) } & \multirow{2}{*}{$\begin{array}{c}\text { Gross } \\
\text { return } \\
\text { (₹) }\end{array}$} & \multirow{2}{*}{$\begin{array}{c}\text { Net } \\
\text { Return } \\
\text { (₹) }\end{array}$} & \multirow{2}{*}{$\begin{array}{l}\text { B:C } \\
\text { ratio }\end{array}$} \\
\hline & & $\begin{array}{c}\text { Grain } \\
\text { (kg/ha) }\end{array}$ & $\begin{array}{c}\text { Stover } \\
\text { (kg/ha) }\end{array}$ & Grains (₹) & Stover (₹) & & & \\
\hline $\mathrm{T}_{1}$ & 26,335 & 433.33 & 830.62 & 43514.99 & 14951.16 & 58466.2 & 32131.2 & 1.22 \\
\hline $\mathrm{T}_{2}$ & 26,907 & 456.67 & 872.40 & 45858.80 & 15703.20 & 61562 & 34655 & 1.28 \\
\hline $\mathrm{T}_{3}$ & 26,907 & 500.00 & 924.40 & 50210.00 & 16639.20 & 66849.2 & 39942.2 & 1.48 \\
\hline $\mathrm{T}_{4}$ & 26,797 & 506.67 & 967.67 & 50879.80 & 17418.06 & 68297.9 & 41500.9 & 1.54 \\
\hline $\mathrm{T}_{5}$ & 26,912 & 716.67 & 1372.67 & 71968.00 & 24708.06 & 96676.1 & 69764.1 & 2.59 \\
\hline $\mathrm{T}_{6}$ & 26,912 & 570.00 & 1009.03 & 57239.40 & 18162.54 & 72723.7 & 45811.7 & 1.70 \\
\hline $\mathrm{T}_{7}$ & 27,914 & 543.33 & 989.80 & 54561.19 & 17816.40 & 75055.8 & 47141.8 & 1.68 \\
\hline $\mathrm{T}_{8}$ & 28,029 & 670.00 & 1292.73 & 67281.40 & 23269.14 & 90550.5 & 62521.5 & 2.23 \\
\hline $\mathrm{T}_{9}$ & 28,029 & 580.00 & 1176.43 & 58243.60 & 21175.74 & 79419.3 & 51390.3 & 1.83 \\
\hline $\mathrm{T}_{10}$ & 27,083 & 506.67 & 1012.53 & 50879.80 & 18225.54 & 69105.3 & 42022.3 & 1.55 \\
\hline $\mathrm{T}_{11}$ & 27,198 & 640.00 & 1052.77 & 64268.80 & 18949.86 & 83218.7 & 56020.7 & 2.05 \\
\hline $\mathrm{T}_{12}$ & 27,198 & 563.33 & 1024.37 & 56569.59 & 18438.66 & 75008.3 & 47810.3 & 1.75 \\
\hline
\end{tabular}

Selling price of greengram grain 100.41 ₹ $/ \mathrm{kg}$

Selling price of greengram stover 18 ₹/kg 
Increase in growth parameter may be due to cell division, enlargement and elongation resulting in overall improvement in plant organs associated with faster and uniform vegetative growth of the crop under the effect of sulphur application. These results are in agreement with the finding of Singh and Aggarwal (1998).

\section{Effect of sulphur sources}

The application of different sources of sulphur differed significantly with respect to growth and yield attributes of mung bean viz. Plant height, number of nodules/plant, number of branches/plant, number of grains/pod, test weight, grain yield and stover yield (Table 3). The parameters increased with increase in application of gypsum followed by single super phosphate at same dose and time of application. Results on the growth parameters indicated that application of gypsum recorded maximum plant height $(76.40 \mathrm{~cm})$, number of nodules/plant (78.33), number of branches/plant (7.67), number of grains/pod (12.17), test weight $(39.67 \mathrm{gm})$, grain yield $(716.67 \mathrm{~kg} / \mathrm{ha})$ and stover yield $(1372.67 \mathrm{~kg} / \mathrm{ha})$ in treatment $\mathrm{T}_{5}(40 \mathrm{~kg} \mathrm{~S} / \mathrm{ha}$ as gypsum $+0.5 \% \mathrm{FeSO}_{4}$ foliar spray $25 \mathrm{DAS}$ ) followed by treatment $\mathrm{T}_{8}$ (40 kg S/ha as single super phosphate+ $0.5 \% \mathrm{FeSO}_{4}$ foliar spray 25 DAS). Maximum seed yield might be due to pivotal role of sulphur in regulating the metabolic and enzymatic processes including photosynthesis, respiration and legume rhizobiun symbiotic nitrogen fixation which reflected in increased yield. The other reasons may be due to the important role of sulphur in energy transformation, activation of enzymes and also in carbohydrate metabolism. The third reason may be due to optimum availability of available sulphur which consequently resulted in well filled pods resulting in increased seed yield of mung bean. These results are in conformity with those of Ghosh and Sarkar (2000). The increase yield in sulphur applied in the form of gypsum may be due to presence of readily available $\mathrm{SO}_{4}$ sulphur in gypsum as compare to single super phosphate. The other reasons may be due to its ability to mobilize more sulphur to the crop plants and gypsum brought remarkable improvement in the physio-chemical properties of the soil. Gypsum application influences the productivity of the crop by improving basic infrastructural frame (bearing capasity) and the leaf area (photosynthate production efficiency as well as pod size). Similar results have been reported by Singh and Aggarwal (1998).

\section{Effect of $\mathrm{FeSO}_{4}$ foliar spray at 25 and 45 DAS}

Influence of single spray of $0.5 \% \mathrm{FeSO}_{4}$ at 25 DAS recorded grain yield $(716.67 \mathrm{~kg} / \mathrm{ha})$ and at 45 DAS $(570 \mathrm{~kg} / \mathrm{ha})$ did not differed significantly. However, these treatments increased the grain yield of mung bean by $65.38 \%$ and $31.53 \%$ respectively, compared to control which recorded minimum grain yield $(433.33 \mathrm{~kg} / \mathrm{ha})$. The application of iron sulphate plays an important role in synthesis of cholorophyll and plant growth regulator (Jin et al., 2008). Iron also improves photosynthesis and assimilates transportation to sinks and finally increases seed and stover yield. This may include increase in carbohydrate synthesis. Similar effect of foliar spray of iron was observed in cowpea in sandy loam soil of Kerala by Anitha et al., (2005).

\section{Economics}

A persual of the table 4 clearly revels that treatment $\mathrm{T}_{5}$ recorded maximum net return of (69764.1), followed by treatment $\mathrm{T}_{8}$ ( 63638.3) giving a $\mathrm{B}: \mathrm{C}$ ratio of (2.59) and (2.23) respectively. 
In conclusion, from the experimental finding it can be concluded that $40 \mathrm{~kg} \mathrm{~S} / \mathrm{ha}$ as gypsum $+0.5 \% \mathrm{FeSO}_{4}$ foliar spray at $25 \mathrm{DAS}$ can be adopted by the farmers for getting maximum yield and returns from greengram crop in eastern U.P.

\section{References}

Anitha, S., Sreenivan, E. and Purushothaman, S.M. (2005). Response of cowpea (Vigna unguiculata L. Walp) to foliar nutrition of zinc and iron in the oxisols of Kerala. Legume Research 28(4): 294296.

Asaduzzaman, (2008), Response of mung bean to nitrogen and irrigation management. American - Eurasian Journal of Agricultural and Enviromental Sciences, 3: 40-43.

Baloch, O.R., Chachar,Q.I. and Tareen, M.N. (2008). Effect of foliar application of macro and micro nutrients on production of green chilies (Capsicum annunum L.). Journal of Agriculture Technology. 4:177-184.

Bernal, M.R. Cases, Picorel, R. and Yruela, I. (2007). Foliar and root $\mathrm{Cu}$ supply affect differently $\mathrm{Fe}$ and $\mathrm{Zn}$ - uptake and photosynthetic activity in soya bean plants. Environmental and Experimental Botany, 60:145-150.

Ghosh, G.K. and Sarkar, A.K. (2000). Efficancy of phosphogypsum as source of sulphur for chickpea (Cicer arietinum L.) in an acid soil. Indian $J$. Agric. Sci.,70(6): 403-403

Guerinot M.L. and Yi, Y. (1994). Jron: nutritions, noxious and not readily available. Plant Physiology 104:815820.

Jin $\mathrm{Z}, \mathrm{M}$ Wang, $\mathrm{L} \mathrm{Wu}, \mathrm{J} \mathrm{Wu}$ and $\mathrm{C}$ Shi, (2008). Impacts of combination of foliar iron and boron application on iron biofortification and nutritional quality of rice grain. Journal of Plant Nutrition, 31: 1599-1611.

Mengel,K. and krikby, E.A. (1987).Principles of Plant Nutrition, IPI, Bern, Swizerland.

Sawan, Z.M., Hafez, S.A. and Basyony, A.E. (2001). Effectof phosphorus fertilization and foliar application of chelated zinc and calciumon seed, protein and oil properties of cotton. Journal of Agriculture sciences 136:191-198.

Singh, Y.P. and Aggarwal, R.I. (1998). Effect of sulphur sources and levels on yield, nutrient uptake and quality of black gram (Phaselous mungo L.).Indian J. Agron.43(3): 448-452.

Tabassum, A.,Saleem, M. and Aziz, I. (2000). Genetic variability, trait association and path analysis of yield and yield components in mung bean [Vigna radiata (L.) Wilezeek]. Pakistan Journal of Botany. 42:3915-3924.

Tandon, H.L.S.and Messick, D.I. (2002). Practicle Sulphur Guide. The Sulphur Institute, Washington,D.C. pp.20.

Yang, J.K., Yuan, T.Y., Zang, W.T., Zhour, J.C. and Li, Y.G. (2008). Polyphasi characterization of mung bean (Vigna radiata L.) rhizobia from different geographical regions of china. Soil. Biol. Biochem.40(7): 1681-1668.

\section{How to cite this article:}

Atul Kumar Saini and Rajesh Singh. 2017. Effect of Sulphur and Iron Fertilization on Growth and Yield of Greengram [Vigna radiata L.]. Int.J.Curr.Microbiol.App.Sci. 6(6): 1922-1929. doi: https://doi.org/10.20546/ijcmas.2017.606.224 